Helgoländer wiss. Meeresunters. 24, 45-53 (1973)

\title{
UWL "Helgoland" - an underwater laboratory for rough sea conditions
}

\author{
G. LUTHER \\ Biologische Anstalt Helgoland (Zentrale); \\ Hamburg 50, Federal Republic of Germany
}

\begin{abstract}
KURZFASSUNG: UWL „Helgoland" - ein Unterwasserlaboratorium für rauhe Seebedingungen. Die rauhen Seebedingungen in der Deutschen Bucht (südliche Nordsee) (Wellenperiode bis $8 \mathrm{sec}$, Wellenhöhe bis $8 \mathrm{~m}$, Tidenstrom bis $1 \mathrm{~m} / \mathrm{sec}$ und Sichtweite um $1 \mathrm{~m}$ ), haben die technische Konzeption von UWL "Helgoland“ und alle Betriebsabläufe (z. B. Transport, Absenken, Uberwachung und Dekompression) maßgeblich beeinflußt. Das UWL unterscheidet sich daher wesentlich von anderen bisher eingesetzten Systemen ähnlicher Größenordnung. Spezielle Probleme und Problemlösungen werden erläutert.
\end{abstract}

\section{INTRODUCTION}

The "Institut für Flugmedizin", especially H. HarTManN, wanted to test decompression tables for $\mathrm{N}_{2} / \mathrm{O}_{2}$ mixtures obtained in a dry compression chamber, under actual working conditions in the sea. The "Biologische Anstalt Helgoland", in particular O. KINNE, wanted to investigate the fauna and flora near the bottom under in situ conditions. Joining forces in 1966, the plan to build and to test UWL "Helgoland" was born. The "Bundesminister für Bildung und Wissenschaft" (Ministry for Education and Science), Bonn (FRG), made the necessary funds, about 1 million DM, available.

The engineer, H. D. Fust (Institut für Flugmedizin, Bad Godesberg), worked out the conception and headed the project and operation phases. After a design and construction period of only 9 months, UWL "Helgoland" was lowered to the North Sea bottom in July, 1969. The first mission near Helgoland at a depth of $21 \mathrm{~m}$ was successful. It lasted from July 28 to August 19, 1969 (KINNE \& RufF 1969, KinnE 1970a, b, c, d, Fust \& OSER 1970, RufF 1970, Krumbein 1971, UhLig 1971), and was directed by Professors O. KINNE and S. RuFr.

In addition to a number of important marine biological results the first manned mission of UWL "Helgoland" made clear that optimum efficiency requires a permanent technical operation staff. In 1970, the personnel costs requested were provided by the Deutsche Forschungsgemeinschaft (DFG). In 1971, the "Helgoland"-system was overhauled and modernized. The new staff operated the system successfully in a Baltic Sea harbour from August 18 to end of September. 
In 1972, Professor KINNE suggested to transfer the technical responsibility for the UWL-system to the "Gesellschaft für Kernenergieverwertung in Schiffbau und Schiffahrt mbH" (GKSS). The GKSS now entertains a special branch devoted to marine technology which will be responsible for the future development of UWL-systems in the Federal Republic of Germany. In 1973, the UWL-system "Helgoland" will be operated again near Helgoland. Marine biologists plan to investigate environmental and behavioural problems employing the underwater laboratory as a research tool, and physicians and technologists will carry out own specialized programmes.

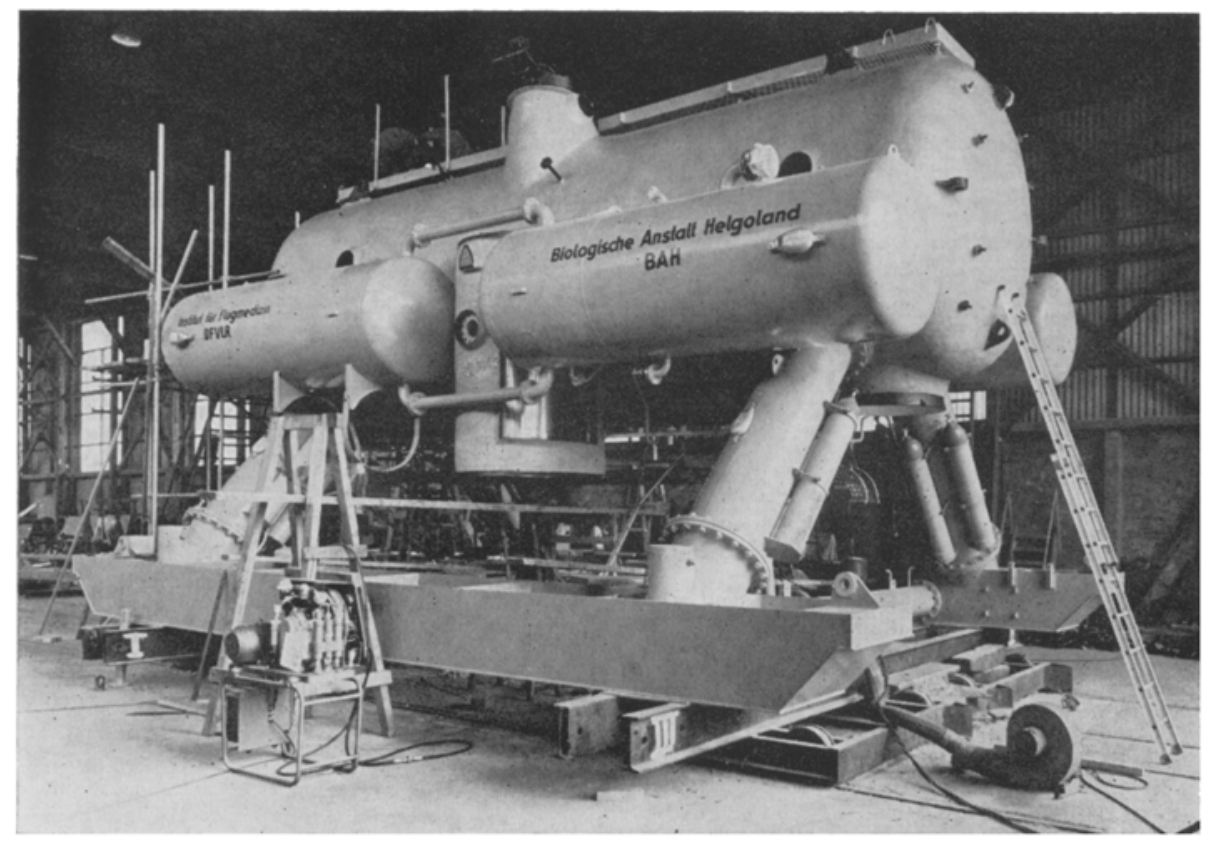

Fig. 1: View of the Underwater Laboratory "Helgoland". (Photo: Dräger-WWerke, Lübeck)

\section{THE UWL "HELGOLAND" SYSTEM}

The system components are: 1 UWL-main body, 1 underwater-igloo, 1 underwater-depot, 1 personnel transfer capsule (PTC), 1 one-man rescue chamber (ERC), 2 underwater gas-bottle batteries for $\mathrm{N}_{2}$ and $\mathrm{O}_{2}, 1$ underwater brake, 1 submerged buoy for the decompression line, the water supply and the second radio system, 3 supply pots, 1 surface energy station, 1 main-decompression chamber (DDC), the supply boat "AM-2", the supervising centre and other components. The main body consists of the dwelling room $(\varnothing 2500 \mathrm{~mm}$, length $2500 \mathrm{~mm}$ ), the instrumentation and machinery room $(\varnothing 2500 \mathrm{~mm}$, length $6500 \mathrm{~mm}$ ), and from 1973 a wet room $(\varnothing 2500$ $\mathrm{mm}$, length $4000 \mathrm{~mm}$ ). The dwelling room serves also as room for underwater decompression of the aquanauts. The wet room can be used as storage room and as laboratory for handling wet products. It is possible to install a large cage for maintaining 
crustaceans, fishes, etc. As in a normal house, in the main body there is a kitchen, toilet, shower and furniture such as work tables, seats, cupboards, beds, etc. Optimal arrangement of installations has made it possible to achieve considerable freedom of movement in spite of the small total volume of about $42 \mathrm{~m}^{3}$. To allow for supply interruptions due to extreme sea conditions, the UWL "Helgoland" system is fitted with a 10-day emergency supply. Normally, high pressure air, oxygen, nitrogen, helium, fresh water and electrical power is supplied from the surface energy station "Füstchen". This energy station is controlled by the aquanauts in the main body of the habitat. "Füstchen" serves as relay station for the radio and TV communication systems. A second radio system uses the submerged part of the buoy as relay station.

Corresponding to the local partial pressure of oxygen, ranging from 0.2 to 0.3 ata, and the water depth of $21 \mathrm{~m}$, the nitrogen concentration increases to $92 \%$. Relative humidity ranges from 70 to $80 \%$. As a function of pressure, the temperature within the UWL will be raised to about $25^{\circ} \mathrm{C}$. Alarms from the UWL are transmitted by radio to the supervising station on land, which is manned day and night.

The external view of the UWL "Helgoland" is shown in Figure 1.

\section{TECHNICAL REQUIREMENTS FOR THE UNDERWATER LABORATORY}

\section{Waves}

Maximum wave period in the German Bay amounts to about $8 \mathrm{sec}$ (in winter the maximum wave period may even go up to $10 \mathrm{sec}$ ). Waves may reach a height of about 7 to $8 \mathrm{~m}$ during storms. According to the airy-wave-theory, the maximum horizontal particle-velocity at a depth of $21 \mathrm{~m}$ is about $1.5 \mathrm{~m} / \mathrm{sec}$; adding the velocity of the tidal currents, the UWL must withstand an oscillation force resulting from a horizontal particle velocity of $2.5 \mathrm{~m} / \mathrm{s}$. The velocity, which is a function of wave period, changes the sign every $4 \mathrm{~s}$.

Maximum vertical particle velocity at UWL depth is also about $1.5 \mathrm{~m} / \mathrm{sec}$. This oscillating force influences all movable equipment attached to the UWL; for example, cables, umbilical line, and long pipes. All outer parts must be protected against resonance with the oscillating forces.

A second type of oscillating force results from pressure changes caused by wave height and wave celerity. Using the airy-wave theory, the maximum pressure difference at UWL depth is equivalent to a water column of about $1.7 \mathrm{~m}$. The height of level oscillation is a function of pressure difference and activated gas volume. If the door to the wet room is closed, the level within the entrance to the wet room goes up and down with an amplitude of $90 \mathrm{~mm}$. When the total volume of wet plus dry room can be used, the water level at the wet room entrance moves up and down every $8 \mathrm{~s}$ with an amplitude of $270 \mathrm{~mm}$. The resulting pressure changes cause an oscillating force on the whole underwater structure with a stress cycle of about 10,000 per day. Resting on the bottom in the winter of $1969 / 1970$, the UWL absorbed more than 400,000 cycles of stress. This load must be taken into consideration when projecting underwater structures for use in shallow waters. 
Another negative influence of the oscillating forces is the high value of gas exchange, which influences all parts of devices protected by an open gas volume. The first UWL battery package was lost through this influence during the unmanned test period. The gas volume is now regulated automatically within the battery cap. The pressure changes constitute a severe stress for the ears of the aquanauts. It is important, therefore, to have a completely closed room available during periods of high wave activities.

\section{Tides}

Near Helgoland, tidal currents up to $1.0 \mathrm{~m} / \mathrm{sec}$ have been measured. Low tides approach the operation site from south-east, high tides from north to north-east. During tidal change, both currents converge; the directions of convergence are different at the surface and at the sea floor. The tidal elevation ranges from $2.5 \mathrm{~m}$ to $3 \mathrm{~m}$. In order to minimize the force acting on the UWL-systems, the direction of the longitudinal system axis should be parallel to the main direction of tidal currents and of waves during stormy periods. For this reason, the longitudinal axis of the UWLsystems pointed from $210^{\circ}$ to $30^{\circ}$ (SSE to NNW). Tidal elevations periodically compress the gas volume within the UWL. Therefore, it is necessary to have sufficient balance volume available in the entrance to the system. Of course, it is also possible to balance the system by level controller combined with higher gas loss. UWL "Helgoland" requires a balance volume of about $6 \mathrm{~m}^{3}$ or $18 \mathrm{Nm}^{3}$. Another effect of tidal elevations is the pressure which sometimes remains in normally balanced subsystems. If the waste tank was cleared during high tide by air, opening the valves during low tide the waste ran in the wrong direction. It is necessary to test the system during the design period in order to avoid such malfunctioning.

Water currents also undermine nearly all devices in direct contact with the sandy sea bottom. This effect, however, was not observed during the mission. Presumably, the undermining effect is a function of horizontal plate-area size around a tube, and of the diameter of the tube itself. During the next operation period this problem will be investigated.

Tidal elevations cause temporarily increased pressures at the sea bottom. Hence, decompression tables must take such pressure variations into account. This applies, of course, to the maximum vertical distance available for operations of fully saturated aquanauts.

\section{Temperature}

In May, the water temperature of the North Sea (near the surface) is about $6^{\circ}$ to $8^{\circ} \mathrm{C}$; in summer, about $17^{\circ} \mathrm{C}$. To our knowledge "Helgoland" is the first UWL which employs external insulation. Several insulation problems were encountered during the first missions. At first, Foamglass ${ }^{\circledR}$ was used as insulation material. This material has good physical properties for marine use, but it was impossible to fit the raw material to the UWL surface without allowing the ambient water to penetrate. An attempt was made to fill all spaces with tar; but the tar hardened before entering all 
the holes. After lowering the underwater laboratory to the sea bottom, sea water found its way through the holes and the wall corroded slightly. Upon lifting the UWL, the enclosed air decompressed; thus the contact between wall, $\operatorname{tar}$ and Foamglass ${ }^{\circledR}$ was loosened. Last year, the UWL was insulated with 14 layers of pu-foam (density $\left.200 \mathrm{~kg} / \mathrm{m}^{3}\right)$. The pu-foam was brought to the wall by a new free-spraying method. The pu-foam insulation was protected against knocks by a resin reinforced with fibreglass. No holes could be detected between wall and insulation; nevertheless, compression and decompression of the UWL by lowering or lifting caused a separation. The insulation freed itself from the wall, too, and sea water entered the space between wall and insulation. This is more a problem of corrosion than insulation. The problem must be solved in the near future.

In the cold waters of the North Sea and the Baltic Sea, excessive heat loss of the aquanauts must be prevented. What good is it to use an UWL if the aquanauts cannot work in the sea for extended periods? Using the new Aquasport ${ }^{\circledR}$ diving suit, it was possible, with interruptions, to work in the sea for 4 to $5 \mathrm{hrs} / \mathrm{day}$. It might be possible to work for 2 hrs without coming back to the UWL to warm up. We hope that better diving suits will become available in the near future.

Low air temperatures bring many problems to the logistic staff at the surface. This is especially true for the surface divers who supply the UWL with piece goods. Of course, it would be best to operate the UWL system without the need for surface divers.

\section{Visibility}

Visibility in the Southern North Sea ranges from 0 to $10 \mathrm{~m}$, with an average of 3 to $4 \mathrm{~m}$ in summer. These ranges must be taken into account in all safety regulations. Normally, visibilities from 1 to $4 \mathrm{~m}$ are considered a handicap for scientific diving. But most oceanologists work at short distance from their objects. Such close-range operations facilitate "Man in the sea" programmes under conditions of poor visibility. Many operations performed in situ are executed at a distance of $1 \mathrm{~m}$ or less. While it has been possible to take excellent photographs at short distances, there is too much "snow" for good filming at normal distances. TV usually yields better results.

\section{Biological activity}

Intensive attachment, settlement and growth of marine organisms resulted in considerable overgrowth after a 1-month mission in the Baltic Sea. The resulting cover, however, has little influence on the function of the whole system; but barnacles present a problem. They settle on, and cover, movable parts of ball valves within a short time.

If the valve is opened, the hard limestone shell tends to damage seal and valve body. Consequently, all valves located externally have been changed in design; the openings now lead downwards. Immediately after the UWL has reached the sea bottom, the openings are filled with nitrogen gas.

The high rates of sedimentation result in high microbiological activities, and these 
- in turn - augment corrosion of all parts exposed to slow water movement. We have, therefore, filled all spaces between flanges with a special lubricant.

\section{Technical requirements for the energy station "Füstchen"}

Wate: movements at the sea surface are more extreme than at $23 \mathrm{~m}$ depth; during severe weather conditions, it is almost impossible to moor a ship without damage. To erect a fixed platform would cost more than the whole UWL system. H. D. Fust decided, therefore, to use a buoy. There are two possible buoy concepts. The first is to install an inertially stabilised buoy like the buoys chosen for the world-wide data gathering system; second to employ a floating buoy. For UWL "Helgoland" the second type was chosen. The main reason for this decision was money. The surface energy station "Füstchen" cost less than DM 200 000.-. Energy supply from a surface buoy was a first, and many problems had to be solved.

The functions of the buoy comprise: (1) Energy supply, i.e. electric power and high pressure air; (2) relay station for the communication systems (radio, TV, telephone); (3) storage container for fuel and gas bottles; (4) floating end point of umbilical line.

A floating buoy requires special installation designs. Critical components of the buoy were tested on a roll test facility.

The buoy is anchored by 3 chains, each $80 \mathrm{~m}$ long, to 3 tetrapods each weighing $4 \mathrm{t}$. The umbilical line is connected to the foot of the buoy by a universal coupling. The umbilical line follows the movements of the sea (tides and waves) with minimum stretch on the fixed ends; it is shaped in the form of a goose neck by additional positive and negative buoyancy.

There was one major problem: numerous sessile organisms attached themselves to the surface of the cable and grew, near the surface, to a total thickness of about $50 \mathrm{~cm}$ within a short time. The added weight seriously reduced the positive buoyancy.

The functioning of the buoy was controlled by aquanauts from inside the UWL. The energy supply proved to be highly reliable.

\section{Operations}

Before shipping, the UWL main body is pressurized and balanced to a positive buoyancy of 3 t. In 1971, the UWL main body was towed by a single ship at a velocity of about 5 knots (Baltic Sea) at wave heights ranging from 0.5 to $1 \mathrm{~m}$. The steel towing rope was connected to the middle of one chain which ended on the two skids of the UWL. Hence the tug of the towing ship lifts the front of the UWL main body slightly during transportation. There was very little rolling or drifting. The siphon in the waste tube was broken by oscillating surface forces. This demonstrates that no long or free linings should be installed.

The UWL system is characterized by a high degree of flexibility; it can be operated at different sites and transported within a short period without the assistance 
of a floating crane. The total resulting operation costs of the "Helgoland" System are low compared to similar UWL systems. In 1969, UWL "Helgoland" was lowered by free negative buoyancy under favourable weather conditions. To exclude unwanted effects of high tide, currents, wind, waves, etc., the next lowering will be carried out with positive buoyancy in combination with a lift bag and two ground weights. One of the ground weights lies directly on the predetermined UWL position. If the lift bag is filled with air, the positive buoyancy is compensated and the UWL is lowered to the desired position. All gas cups must be filled completely in order to exclude water damage to gas-protected parts of the system, for example, to the battery package.

Each of the 4 legs of UWL "Helgoland" is fitted with a wheel. According to tidal current direction, one leg is selected for lifting the supply container. Upon reaching the surface, the supply ship takes over the container and connects a filled container to the end of the rope. The supply container has little positive buoyancy; the aquanauts draw it down and transport it to the entrance of the UWL. The proper functioning of this system must be tested in 1973.

During bad weather, aquanauts can be surfaced only with great difficulties by the personnel transfer capsule (PTC) or the emergency rescue chamber (ERC) and brought to the deck decompression chamber (DDC). Hence aquanauts are decompressed within the UWL. This method requires the supervising physician to be a diver; furthermore, additional medical instruments and pharmaceuticals must be stored within the UWL. After decompression, aquanauts swim to the surface.

Due to poor visibility, it is not possible to control the activities of the aquanauts from the surface. In order to reduce rescue time, the underwater operation area is limited. Its periphery is marked by ropes, the area itself by marking lines. The underwater igloo is located and anchored near the main research field. The igloo is fitted with wire communication (to the UWL), a $\mathrm{CO}_{2}$ absorber, light, two 501 high pressure bottles and a pinger. Additional SCUBAs are stored in the igloo during manned missions.

Each SCUBA used by aquanauts is fitted with two regulators, one for reserve. The aquanaut outside can contact the UWL by wireless underwater communication (system Aquasonic $812^{\circledR}$ ) and by sonar (system Ametek Straza). UWL, aquanaut and the main research field each have their own pinger frequencies. Thus, in complete darkness or high turbidity, the aquanaut can locate the UWL, or an aquanaut leaving the UWL can find his externally operating colleague. In 1971, we tested the Aquasonic system 811; it has good speech transmission but poor reliability. It is to be hoped that the new 812 system will perform better.

\section{SUMMARY}

1. The UWL "Helgoland" system has been built with the rough sea conditions in the Southern North Sea in mind: wave periods up to $8 \mathrm{sec}$, wave heights up to $8 \mathrm{~m}$, tidal currents up to $1 \mathrm{~m} / \mathrm{sec}$.

2. The main body can be towed at a velocity of up to 5 knots, and be lowered 
without the assistance of a floating crane. The system has a high degree of flexibility.

3. In order to withstand the oscillating forces caused by sea movements, a horizontal cylinder was chosen as main body. The main body is ballasted to a negative buoyancy of $16 \mathrm{t}$ (more than for other comparable UWL systems). Four swords stabilize the UWL against horizontal forces. The main body acts as a self-righting body.

4. Emergency supply of food and energy allows complete surface independence for 10 days.

5. Rough surface conditons and poor underwater visibilities do not allow aquanaut activities on the sea bottom to be observed from the surface. A wireless system is used for diver communication on the sea bottom. Three communication systems connect the UWL main body to the supervising station on land: one TV and two radio systems. One radio system is used to transmit alarms to the land base, the other will be used in 1973 as transmission system for oceanological data.

6. Aquanauts cannot be transported from the habitat to the deck decompression chamber (DDC) during rough weather. Hence one room in the UWL main body serves as decompression chamber.

7. The surface energy station, a floating buoy, is a world first. The station operates automatically; it is controlled by aquanauts in the UWL. Electricity, compressed respiratory gases and fresh water are transported from the buoy to the UWL via an umbilical line. Due to tide and wave motion, the umbilical line is shaped in goose-nedk fashion. Other suplies such as food and mail are brought to the UWL by supply containers without assistance from surface divers. Supplementary respiratory gas for the semi-closed diving apparatus is stored on the sea bottom; the same applies for nitrogen.

8. The first manned test period in August, 1969, and the subsequent 9-month unmanned period proved that the system is able to withstand rough sea conditions.

9. As a research base, UWL "Helgoland" has met the expectations. It is possible to work and to conduct research in the sea, even under the adverse conditions prevailing in the North Sea. In 1973, UWL "Helgoland" will operate again on the sea bottom near Helgoland.

\section{LITERATURE CITED}

Fust, H.-D. \& OsER, H., 1970. Die technischen und medizinischen Erkenntnisse aus dem Einsatz des „UWL Helgoland“. Meerestechnik 1, 17-23.

KINNE, O., 1970a. Erste Erfahrungen mit dem Unterwasserlaboratorium „Helgoland“. Meerestechnik 1, 1-5.

- 1970b. Erste Exfahrungen mit dem Unterwasserlaboratorium „Helgoland“ (UWL-H) (Zweiter Teil). Systems 69. (Internationales Symposium über Zukunftsfragen.) Dt. Verl. Anst., Stuttgart, 293-301.

- 1970c. Unterwasserlaboratorium "Helgoland “. Ein naturwissenschaflich-technisches Pionierunternehmen. Naturwissenschaften 57, 480-487.

- 1970d. Unterwasserforschung mit dem UWL-H. Umschau 10, 304-307.

- \& RufF, S., 1969. Unterwasserlaboratorium „Helgoland“. Bild. Wiss. 1969, 1176-1183. 
Krumbern, W. E., 1971. Sediment microbiology and grain-size distribution, as related to tidal movement, during the first mission of the West German Underwater Laboratory "Helgoland". Mar Biol. 10, 101-112.

RuFF, S., 1970. Erste Erfahrungen mit dem Unterwasserlaboratorium „Helgoland“ (Erster Teil). Systems 69. (Internationales Symposium über Zukunftsfragen.) Dt. Verl. Anst., Stuttgart, 286-292.

UhLIG, G., 1971. Ersterfahrungen mit dem Unterwasserlaboratorium „Helgoland“. Dräger Tauchtechnik 5, 35-45.

Author's address: Dipl.-Ing. G. Luther

Gesellschaft für Kernenergieverwertung in Schiffbau und Schiffahrt mbH 2054 Geesthacht-Tesperhude

Federal Republic of Germany 